OPEN ACCESS

Approved by:

Frontiers Editorial Office,

Frontiers Media SA, Switzerland

${ }^{*}$ Correspondence.

Xuewu Zhang

zhangxuewu@ybu.edu.cn;

zhangxuewu18@163.com

Specialty section:

This article was submitted to

Molecular Medicine,

a section of the journa

Frontiers in Cell and Developmental

Biology

Received: 05 January 2021

Accepted: 06 January 2021

Published: 21 January 2021

Citation:

Ye T, Liang $Y$, Zhang D and Zhang $X$ (2021) Corrigendum: MicroRNA-16-1-3p Represses Breast

Tumor Growth and Metastasis by Inhibiting PGK1-Mediated Warburg Effect. Front. Cell Dev. Biol. 9:649787. doi: $10.3389 /$ fcell.2021.649787

\section{Corrigendum: MicroRNA-16-1-3p} Represses Breast Tumor Growth and Metastasis by Inhibiting PGK1-Mediated Warburg Effect

\author{
Tianxing Ye ${ }^{1,2}$, Yingchun Liang ${ }^{2}$, Deyu Zhang ${ }^{2}$ and Xuewu Zhang ${ }^{1 *}$ \\ ${ }^{1}$ College of Medicine, Yanbian University, Yanji, China, ${ }^{2}$ Department of Medical Molecular Biology, Beijing Institute of \\ Biotechnology, Collaborative Innovation Center for Cancer Medicine, Beijing, China
}

Keywords: the Warburg effect, PGK1, miR-16-1-3p, cell proliferation, metastasis

\section{A Corrigendum on}

MicroRNA-16-1-3p Represses Breast Tumor Growth and Metastasis by Inhibiting PGK1-Mediated Warburg Effect

by Ye, T., Liang, Y., Zhang, D., and Zhang, X. (2020) Front. Cell Dev. Biol. 8:615154. doi: $10.3389 /$ fcell.2020.615154

An author name was incorrectly spelled as Tianxin Ye. The correct spelling is Tianxing Ye.

The authors apologize for this error and state that this does not change the scientific conclusions of the article in any way. The original article has been updated.

Copyright (c) 2021 Ye, Liang, Zhang and Zhang. This is an open-access article distributed under the terms of the Creative Commons Attribution License (CC BY). The use, distribution or reproduction in other forums is permitted, provided the original author(s) and the copyright owner(s) are credited and that the original publication in this journal is cited, in accordance with accepted academic practice. No use, distribution or reproduction is permitted which does not comply with these terms. 